\title{
Population and development: An introductory view
}

\section{Geoffrey McNicoll}

Population Council

Follow this and additional works at: https://knowledgecommons.popcouncil.org/departments_sbsr-pgy

Part of the Demography, Population, and Ecology Commons, Family, Life Course, and Society Commons, and the International Public Health Commons How does access to this work benefit you? Let us know!

\section{Recommended Citation}

McNicoll, Geoffrey. 2003. "Population and development: An introductory view," Policy Research Division Working Paper no. 174. New York: Population Council. 


\section{Population and Development:} An Introductory View

\section{Geoffrey McNicoll}




\title{
Population and Development: An Introductory View
}

\author{
Geoffrey McNicoll
}

Geoffrey McNicoll is Senior Associate, Population Council, New York.

This brief account is made up of material prepared for two forthcoming encyclopedia entries: "Population and development," in the Encyclopedia of Population, ed. Paul Demeny and Geoffrey McNicoll (New York: Macmillan Reference, 2003) and "Demographic transition," in the Oxford Encyclopedia of Economic History, ed. Joel Mokyr (New York: Oxford University Press, in press). 


\begin{abstract}
A brief overview of the relationships between population change and economic development, written for readers unfamiliar with the subject. The paper touches on the scale and pace of world development, the economic consequences of population size and rate of growth, patterns of demographic transition, and the scope for policy measures aimed at speeding that transition.
\end{abstract}

This material may not be reproduced without written permission from the author. For a list of Policy Research Division Working Papers, including those available for downloading in PDF format, see www.popcouncil.org/publications/wp/prd/rdwplist.html. 
Economic development refers to the structural transformation of human society from subsistence economy to urban-industrialism, and to the sustained rise in productivity and income that results. The transformation is seen in the structure of production, consumption, investment, and trade; in financial and other economic institutions; in occupations, educational levels, health conditions, and rural-urban residence; and in people's perceptions of the social and natural worlds and of their own agency. Political development is in some respects an overlapping process, yielding the institutions and values of the democratic state. "Development," however, is commonly taken to mean economic development.

Development is linked in various ways to population change. The transformation in demographic regimes from high to low death and birth rates - the demographic transition — can be added to the list of structural changes constituting development: indeed, in terms of its direct effect on human well-being and its social and economic implications, it is arguably the most important of those changes. Population growth, unleashed by mortality decline or migration, is a force of its own in the development process, sometimes seeming to promote development, at other times impeding it, and always diluting its achievements. While countries are the principal level at which such relationships are identified, effects at the local level are often sharper. And population change can also have implications for broader regional development and even for the global economy-directly through migration and disease transmission or indirectly through effects on geopolitics and major environmental systems. Breaking down population growth by age group, source (in particular, natural increase versus migration), and other characteristics reveals further links. The subject of population and development is concerned broadly with all such interactions: with how populations and economies impinge on each other and with the consequences that ensue.

\section{SCALE AND PACE OF DEVELOPMENT}

In the early 1800 s, with industrialization barely underway, the world population stood at one billion; as late as 1930 it had reached just 2 billion; by the end of the twentieth century it had passed 6 billion. While dramatic enough to be described as an "explosion," this growth in population seems almost modest in comparison to the ex- 
pansion of the global economy in the same period. Angus Maddison's index of gross world product (at constant prices, though the calculations required are complicated and inherently somewhat dubious over these time intervals), set at 1 in 1820, reaches 5 in 1929, 40 in 1990 (Maddison 1995). It had probably exceeded 50 by 2000.

Along both dimensions this growth was extraordinarily uneven. The populations of Europe and North America expanded markedly over the nineteenth century as mortality yielded to improved living standards, the spread of education, and early public health measures. The region's share of the world population rose from about one-fifth to about one-third. Subsequently, mortality declines spread to Latin America, Asia, and Africa, creating a dramatic surge in population growth rates-and shifts in the global demographic balance that are relegating Europe and North America to the world's demographic margins (a 17 percent population share in 2000, a projected 12 percent share by 2050). The large reductions in mortality have been perhaps the most remarkable achievement of the post-World War II world. Life expectancy in the developing countries rose from about 40 years in 1950 to an estimated 65 years at the beginning of the twenty-first century.

Fertility levels followed, or seem to be following, the same regional course. In the West, aside from some forerunners (France and the United States), the decline got broadly underway in the late nineteenth and early twentieth century, spreading to the nonindustrialized world after World War II but becoming widespread only in the 1960s or later. (Some regions, notably much of sub-Saharan Africa, had shown scant decline by the end of the twentieth century.)

Estimated birth and death rates over the course of demographic transition in three classic cases-France, England and Wales, and Japan — are graphed in Figure 1. The picture for England is characteristic of the usual textbook stylization of the transition, with fertility change lagging mortality. France is distinctive in the coincidence of the two declines, hence with comparatively little population growth over the period.

The picture of regionally staggered onsets of demographic transition around the world, eventually (if only after a tenfold or more rise in population size) leading to conditions of low, zero, or perhaps negative population growth at low mortality levels, suggests a large measure of commonality in demographic experience. In cross-section, however, it is the diversity of demographic situations that is most striking. In the early decades 
Figure 1 Annual birth and death rates per 1000 population over the course of the demographic transition for France, England and Wales, and Japan
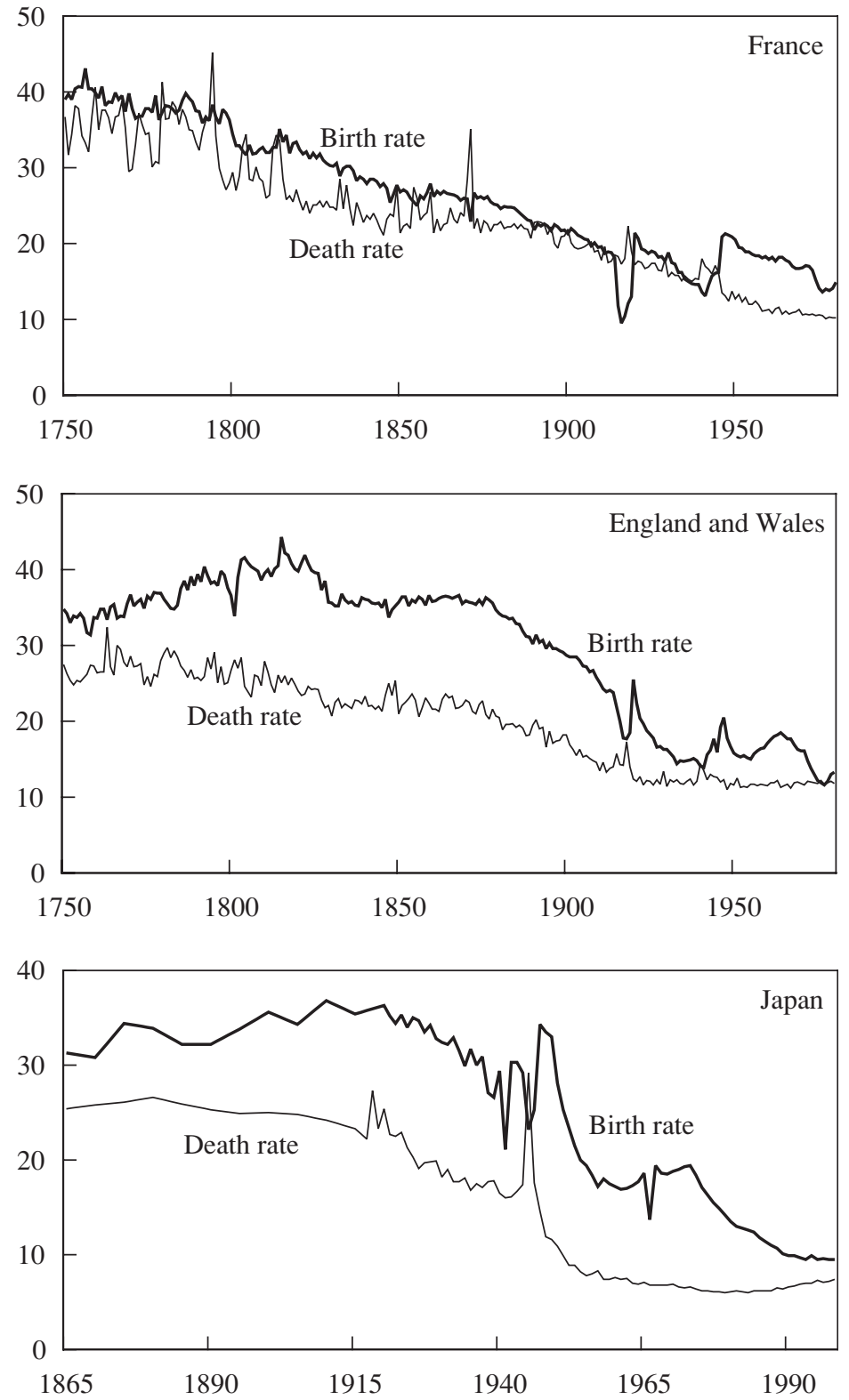

Note: Pre-1920 estimates for Japan are 5-year averages.

Sources of data: Chesnais (1986), Wrigley and Schofield (1981), Ohbuchi (1976), and United Nations Demographic Yearbook (various issues). 
after World War II arraying countries by mortality or fertility levels showed strongly bimodal distributions; in 2000, the bimodality had largely disappeared but the variancereflecting the distance between leaders and laggards in the transition-remained high.

Economic growth used to seem well depicted by a similar kind of staged process, with poor countries successively reaching "take off" speed and embarking on rapid and sustained economic development. That expectation has only partially been borne out. In the worldwide emphasis on development that emerged with the ending of colonial rule after World War II, many countries experienced economic growth spurts, sometimes for long enough to be proclaimed "miracles," but few by the end of the twentieth century had attained income levels comparable to those of the early industrializers. Many countries and some whole regions (sub-Saharan Africa in the 1980s and 1990s) experienced periods of economic stagnation or retrogression. Using a standard measure of absolute poverty — expenditure averaging less than a dollar per day at 1990 purchasing powerthe world's poor numbered around 1.2 billion persons ( 20 percent of the world's population) in the late 1990s.

The variegated global experience of growth in populations and incomes since the industrial revolution is depicted in summary fashion in Figure 2, based on the estimates of Maddison (2001). (The years identified are those selected by Maddison as reflecting significant junctures in global development; the smooth trajectories, of course, skirt over intervening fluctuations.) The chart reveals the contrasts among major countries along both axes: the early economic development of Western Europe with only modest population growth; the large economic and demographic expansion of the "settler societies" of the Western hemisphere; the impressive steepening of the trajectories for China and to a lesser degree India; and the bleak performance of the African region (a doubling of population in the last quarter of the twentieth century with no overall gain in real per capita income).

\section{Population Size AND DEVElopment}

Under the mercantilist doctrine that prevailed in early modern Europe a larger population was valued as a source of a nation's wealth. Malthusianism punctured that belief. From Malthus onward, both popular and official opinion has tended to see population growth as a threat to development. Increases in production could only too easily be 
Figure 2 Population and per capita GDP trajectories, selected countries and regions, $1820-1998$

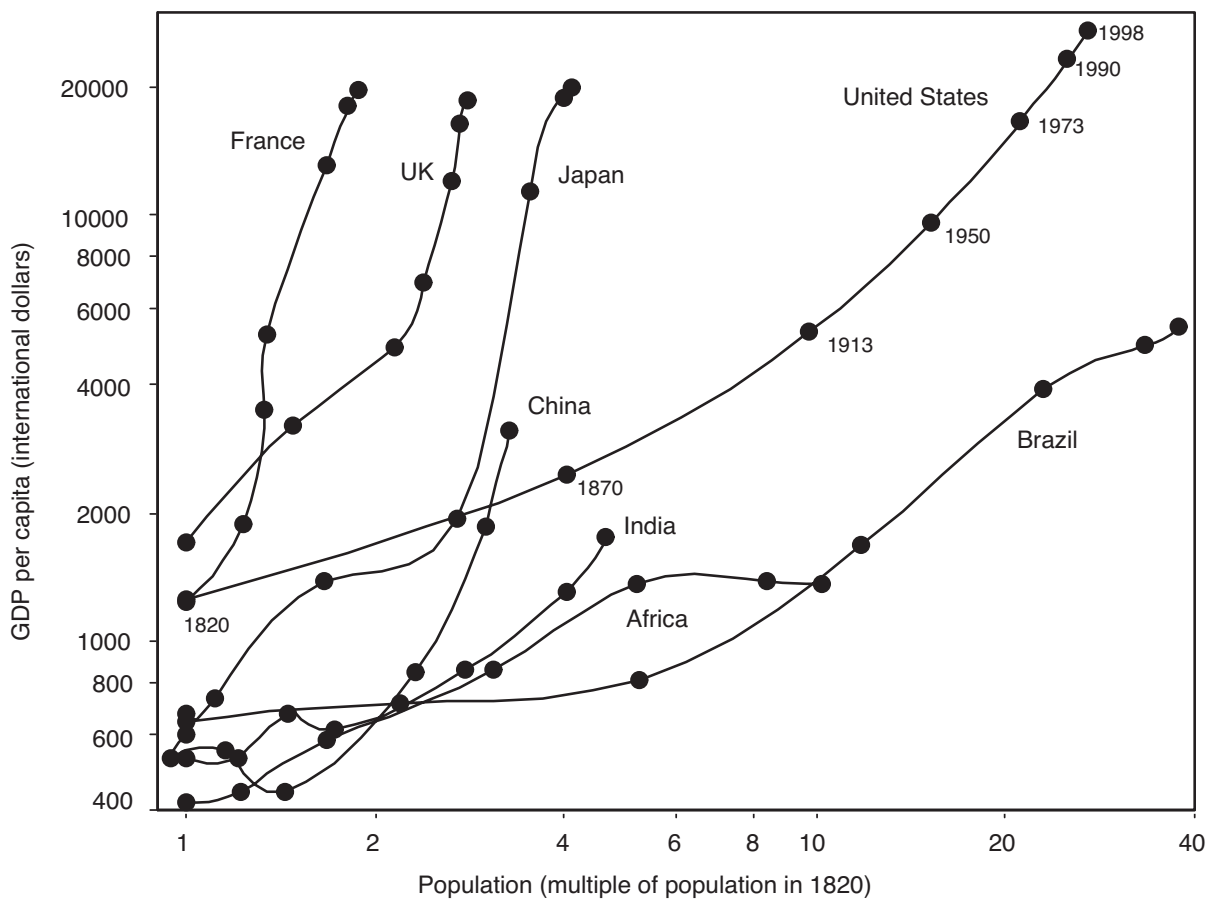

Note: Income in 1990 dollars at purchasing-power parity. The seven points on each trajectory refer, left-toright, to status in 1820,1870, 1913, 1950, 1973, 1990, and 1998.

Source of data: Maddison (2001), Appendix A.

dissipated through additions to population rather than invested in capital accumulation. Resource scarcities - in arable land, later also in other natural resources-were seen as always looming on the horizon and were brought nearer by demographic expansion. Malthusian views lay behind India's concerns about its population growth both prior to and after independence. They were the basis of China's sudden conversion in the 1970s to a policy of hard-nosed birth control. They attained wide prominence in the West in the same decade through the Limits to Growth thesis propounded by environmentalists.

Malthusian thinking had a more chequered history in economics. Resource-dependence has been steadily reduced as technology has advanced and human capital has grown. Nonrenewable resources have found vastly expanded supplies in some cases and ready substitutes in others, banishing fears of an era of diminishing returns and rendering 
earlier worries about the imminent exhaustion of particular resources (coal, for instance) almost quaint. As Barnett and Morse (1963) wrote: "the social heritage consists far more of knowledge, equipment, institutions, and far less of natural resources, than it once did."

Resource constraints cannot be wholly assumed away, especially if development is equated with human well-being. Fresh water is often mentioned as a potentially limiting factor; so-called positional goods, such as unique environments, are by definition scarce (see Hirsch 1976). Standard measures of economic performance mask the effects of changes in the natural environment—or in the "environmental services" it provides: these may be a significant ingredient of human welfare, but yet remain statistically invisible. Aesthetic criteria generally, and hence a whole range of quality distinctions-in production and consumption as well as in environmental conditions-tend to be neglected when it comes to measurement.

Population-resource interactions are mediated by human institutions: markets or management regimes that serve to ration access to the resource by potential users. In some circumstances, these procedures break down, or possibly they never emerged in the first place, leading to depletion or degradation as the demands on the resource increase. A classic stylized account of this, intended to model possible external effects of population growth, is Garrett Hardin's (1968) "tragedy of the commons." The tragedy is the decline through overuse - and through institutional ineffectiveness - of an openaccess, common-property resource. Analogues of these local-level problems may exist at higher levels of social organization, even internationally.

\section{Population Growth AND DEVElopment}

Twentieth-century theorizing about development was influenced by neoclassical growth models that allowed steady expansion of both economies and populations, with technological progress given a central role in outcomes. Any adverse effects of the overall scale of the economy in relation to its resources were assumed negligible—or outweighed by positive effects. Some economists saw population growth actually boosting technological change - a case supported by the work of Ester Boserup on long-run agrarian change. Many others saw population growth as a fairly neutral factor in development performance. The range of viewpoints is captured by two major reports on the 
subject from the US National Academy of Sciences, from 1971 and 1986: the first found a strong economic case for limiting population growth, the second at most a very weak one. Whatever the theoretical arguments, in the post-World War II decades, at least until the 1980s, aggregate income data did not support a significant negative effect of population growth on development: at the country level the years of fastest economic and demographic growth often coincided.

\section{Effects of lower mortality and fertility}

If we ask not about the effects of rapid population growth on development but about those of reduced mortality and fertility, the consensus is clear. As well as its obvious and immediate meaning for a society's welfare (sometimes termed human development), high mortality has various adverse effects on economic development. There is the evident waste of human resources, often embodying substantial public and private investments in education and skills. The AIDS epidemic has been particularly damaging in this respect: in many of the worst-affected countries the disease cuts a swath through the educated strata of the society. High mortality is also associated with heavy morbidity, and sometimes with impaired physical and cognitive development, with detrimental economic consequences. Within families, the death of a parent may harm the educational opportunities and broader life-prospects of the children: again, AIDS mortality is the most prominent case in point, leading to a drastic rise in orphanhood and child destitution in a number of African countries. The benefits for development of improvements in health conditions and lower levels of mortality are thus clearly apparent.

The benefits of a fertility decline are somewhat less obvious-again, aside from the immediate welfare gain if it lessens "unwanted" births or improves reproductive health. Research suggests that lower fertility may improve access to health services and education, and more generally expand opportunities to escape poverty. One important route for such benefits is through a lowering of the child dependency rate: for a period of some two decades after a fertility decline there are fewer dependent children but no fewer workers, freeing up resources for investment. This straightforward proposition, advanced by Ansley J. Coale and Edgar M. Hoover in the 1950s, was the main economic case for the worldwide expansion of family planning programs in the 1960s. Later it lost 
favor, along with many other arguments specific to developing economies, in the general disdain for development economics as a distinct branch of economics. It experienced a revival in the 1990s, coming to be seen by some as an important element in explaining the "economic miracle" of East and Southeast Asian countries from the 1970s to the 1990s. The dramatic falls in birth rates in this region, beginning in the 1960s, are held to have yielded a "demographic bonus" of investment that boosted the development effort — not least, through improvements in human capital. However, the conditions under which any such bonus can be put to good use may be quite exceptional, lessening the value of the Asian miracle as a policy lesson.

\section{Effects of development}

The effects of economic development on mortality and fertility growth are the subject of the "theory" of demographic transition, an often-derided but robust explanation of the empirical observations seen in Figure 1. This theory came into favor and then into disfavor along with modernization theory, to which it has a close connection. In very brief summary, child mortality began to fall as economic conditions improved and early public health measures were adopted. The larger number of surviving children imposed economic pressures on families. At the same time, industrialization and urbanization brought wider cultural horizons and greater opportunities for mobility, both social and geographic. The transformed labor market and rising consumption and investment demands, when translated into effects on the utilities and costs of children (notably, education costs), created conditions favoring smaller families. Parents responded by limiting the number of their children. The process was well described in F.W. Taussig's Principles of Economics, the standard American economics textbook of the early twentieth century.

The contributing factors to the mortality decline have long been clear: more reliable food supplies and better nutrition; improved knowledge and practice of hygiene; public health interventions - in particular, improvement in water supply and sewage disposal; vaccination and other medical advances; better housing; and improved public order. The weighting of these factors in particular historical cases is often a matter of contention. For contemporary poor countries, however, the analogous debate has been 
over the relative significance of medical knowledge transferred from the developed countries, expansion of public health facilities, and improved social and economic conditions. In a pioneering study, Samuel H. Preston (1975) showed that there was a reasonably tight but nonlinear relationship between life expectancy and per capita income among countries at a given time, and that this relationship has shifted systematically over time. The approximate relationship around 1990 is shown as the top curve in Figure 3, based on World Bank estimates: it is steep at low income levels, but flattens out at higher levels. Figure 3 also indicates the shifts in the relationship over time, drawing on sparser historical estimates. The major shifts have been twofold: (1) a decline in the per capita income level (in purchasing-power terms) at which this flattening takes placethat is, in the income level above which further income increases can be expected to make only slight contributions to improving mortality; and (2) an overall upward shift

Figure 3 Relationship between life expectancy and per capita income at different time periods

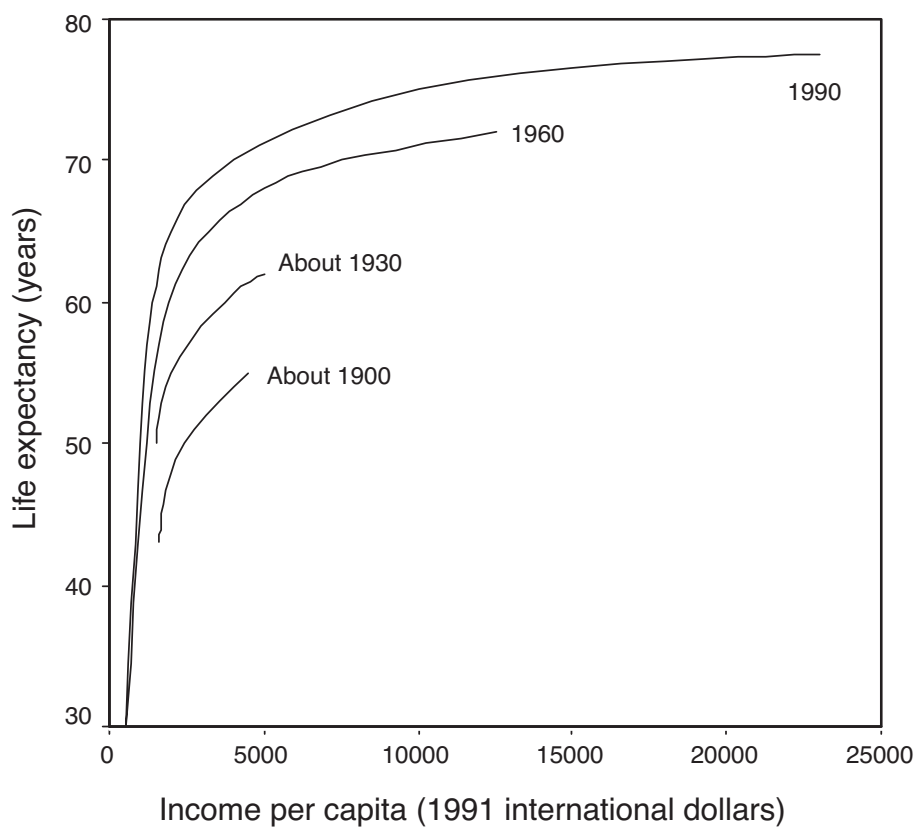

Source: World Bank, World Development Report 1993, after Preston (1975). 
of the life expectancy-income relationship: a country with a given real per capita income today is likely to have considerably lower overall mortality than a country reaching the same income level some decades earlier would have had.

On fertility decline, the large volume of research on the topic has not yielded the degree of convergence that might have been expected. To the extent that fertility decline merely maintains the number of surviving children of earlier and higher-mortality times, fertility transition could be seen as an initially conservative response to changing circumstances. The stimulus for change would be larger numbers of children in the household and increased crowding in the job market (see Montgomery and Cohen 1998). Moreover, since the uncertainties about child survival at the family level are reduced as mortality falls, birth planning makes more sense. Confining family-level responses to the single dimension of fertility change, however, is an arbitrary constraint. Families have migration options, especially in an industrializing economy, and they can make adjustments through changes in productivity and labor supply. A simple rule for fertility transition was not to be expected.

A nine-country empirical study of European transitions, the Princeton European Fertility Project, indeed found as much (Coale and Watkins 1986). There were no uniform socioeconomic thresholds, such as in levels of education or urbanization, marking the onset of the transition. On the other hand, there was often simultaneity of change within regions or language groups, suggesting a process of cultural diffusion of new ideas and behaviors. The fertility transition, in the view of many of the project's participants, took the form of adoption of the innovation of birth control by married couples. The result was a shift from "natural fertility" - where individual-level intentional birth control is absent, even though fertility may be far below its biological maximum-to controlled fertility, where rational decisionmaking by individuals has been extended to family size. Similar interpretations of post-World War II fertility transitions have been drawn from household survey data such as the World Fertility Survey (Cleland and Wilson 1987).

The view of fertility transition as innovative behavior diffusing through a natural-fertility population has in turn been challenged. There is scattered evidence of deliberate birth control (and its near functional equivalent, infanticide) being practiced in 
many pretransitional societies, although the extent to which it influenced their overall levels of fertility is not agreed upon. However, the notion that parents in pretransitional societies simply accepted the number of children that came, with no reference to their economic (or maternal health) interests, has seemed inherently implausible to many researchers - even where there was effective social regulation of fertility. (Such regulation existed at the level of parish or village in much of preindustrial Western Europe and in Japan through the control of marriage or household formation.) Microeconomic theorists of fertility, such as Becker (1990), make the routine assumption that an individualized economic calculus of decisionmaking always applies to reproductive behavior. Some social demographers, such as Caldwell (1982), similarly see fertility decisions in terms of a parental (or paternal) benefit-cost framework. Those decisions are made with reference to price relativities, household budget and time constraints, and a complex array of preferences. Individual perceptions and idiosyncratic valuations of the factors entering fertility decisions introduce a subjective element, but this does not amount to ideational determination of the outcome.

Doubtless here, as with much other human behavior, the material and ideal are thoroughly confounded. New attitudes to reproduction and fuller knowledge of birth control were conveyed through social networks (see Bongaarts and Watkins 1996). At the same time changing economic conditions and expectations were pushing families to shift from investing in social capital to investing in physical and human capital, encouraging a shift from quantity to "quality" of children and thereby a curtailment of childbearing. The income-fertility relationship, shown as a scatter plot in Figure 4, makes clear both that a broad negative relationship exists and that a lot of variance remains to be attributed to other factors. But such factors would necessarily include also the many aspects of development poorly captured by income.

\section{Promoting Demographic Transition}

As discussed above, both mortality and fertility declines are favorable for development. The rapid population growth that is their usual accompaniment (since mortality typically falls first) is an offsetting factor, but moderates as the transition proceeds. Since development in one way or another brings about such declines, these relationships 
Figure 4 Scatter plot of total fertility rate against per capita income for 137 countries, 2000

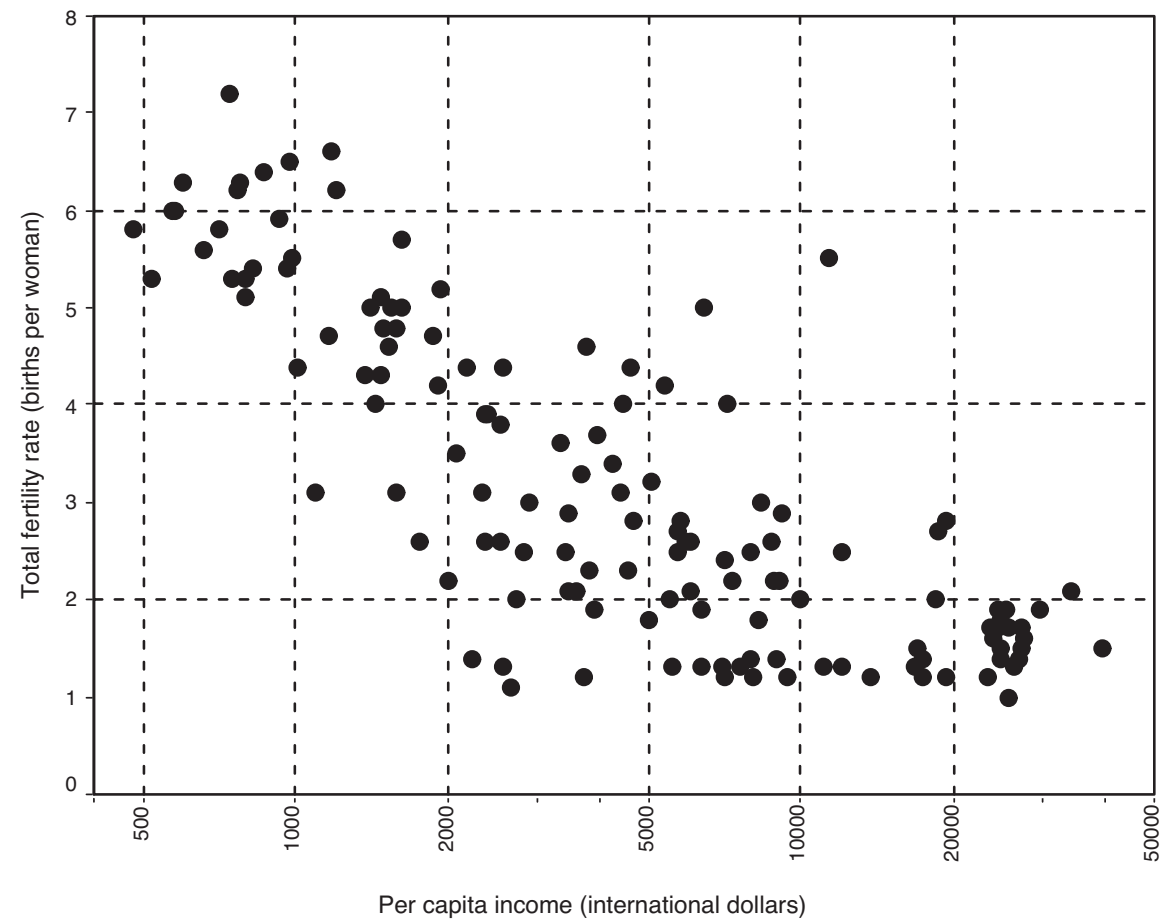

Note: Income at purchasing power parity. Upper-right outlier is Saudi Arabia.

Source of data: World Bank, World Development Indicators, 2002.

can be viewed as positive feedbacks in the process, forming a virtuous circle by which success breeds success: sustained economic growth on the one hand and attainment of a modern demographic regime on the other. The components of population change are ingredients in the overall pattern of development, but for the most part they have the nature of dependent variables. Demographic transition is welcomed for the immediate welfare gains that low mortality and low fertility bring, but the proper policy focus to achieve those gains is on the broad development effort.

Many researchers and development planners, however, would adopt a much less passive stance on health and population policy. If there are proven means of intervention that can speed the mortality and fertility declines, then the gains both for immediate welfare and for the development effort can be reaped much earlier than would otherwise happen. 
For mortality, the appropriate means of intervention were evident. Cross-sectional analysis like that in Figure 3 indicates that the effect of development on mortality is largest for countries at the lowest income levels. At the upper income ranges mortality is increasingly dissociated from economic change, reflecting both an educated demand for health services and the affluence to afford them. In the lower- and middle-income ranges, however, at any given income level there is a diversity of mortality outcomes across countries. Differences in income distribution, levels of (and gender disparities in) education, public health expenditures, and the design and reach of the health system are the main contributors to that diversity. All of these are factors that can potentially be influenced by policy, and in combination can yield mortality levels in a country well below what would be predicted based on its income (see Caldwell 1986).

The degree to which fertility can be affected by policy has been a controversial issue in population and development studies, despite the casual assumption of many that the standard intervention — the family planning program — is of proven efficacy. But interventions of some sort are needed: the "demographic bonus" or any other economic advantages accruing from fertility decline are of interest because of the presumption that there are policy measures that can lower fertility other than through development itself. Otherwise these advantages are reduced to the status of some helpful positive feedback generated by successful development.

By most accounts the main factor behind fertility transition is the falling "demand" for children, traceable to a host of actual and anticipated changes: in survivorship rates, in the family economy, in educational and labor market opportunities, and in related normative images of family and society. Also contributing to fertility decline are greater knowledge and availability of modern contraceptive methods and, in some situations, strong government efforts to promote smaller families.

To what degree do governments have appreciable direct purchase on the demand for children, other than through measures that contribute to development at large? In terms of the benefit-cost framework alluded to above, the answer would probably be: not much. Many of the larger factors impinging on the costs of children are far removed from the reach of policy. For example, an important part of the cost of a child is the opportunity cost of the time entailed in childraising, which increases as new earning 
opportunities or newfound forms of consumption emerge. Government-supported family planning programs can lower the economic costs of birth control, but this may be a minor consideration: the economist Lant Pritchett (1994: 25) points out that, under any reasonable assumption about the economics of children, birth control costs are likely to be no more than a tiny fraction of the (capitalized) net return—or net cost—anticipated from having a child.

The direct costs of children, in particular for education and health services, are substantial, but in most countries these are in some (often considerable) part socialized through centralized public financing. Parents of large families may thus be little disadvantaged. There are obvious sound public policy grounds for that financial design, but it removes a potentially powerful instrument to reduce demand for children. A byproduct of the structural adjustment programs insisted upon by international lenders to poor and heavily indebted countries has been the cutting back of these social expenditures: a move widely decried on welfare grounds, but with possible antinatalist effect.

Separate from policy affecting the economics of children, in some countries in particular periods there have also been administrative pressures brought to bear directly on fertility. Such pressures peaked in the 1970s in Asia, principally in China and (more briefly) India, but also, less rigorously, in Indonesia and some other countries. Except for China, the pressures ebbed with the decline of fertility. Both human and political costs are incurred.

The objections that are widely made to government dictates in matters of fertility behavior and outcomes do not apply to social pressures from kin or community. Such pressures are probably felt less on the direct question of family size (except regarding childlessness and very small families) than on related matters such as age at marriage, approval or disapproval of particular practices of birth control, and restrictions on sex roles. Mostly, such pressures reinforce existing social norms; but social influence also entails scope for "contagion" and "bandwagon" effects that may spread innovative fertility behaviors. However, it is not apparent that population policy can be designed to benefit significantly from this phenomenon. Cases where community outreach has seemingly altered some fertility-related behavior are often better interpreted in terms of changes in the perceptions of incentives and opportunities of the actors themselves: the indi- 
vidual parents. For members of subsistence societies, almost osmotically, but with social influence as one transmission route, visions of the family, of authority, of the future, even of time, gradually come more into alignment with those characteristic of the modern industrialized world.

\section{POPUlATION AND DEVELOPMENT FUTURES}

In broad outline, the global economic and demographic trends observed over the second half of the twentieth century would support an expectation over the next halfcentury of continued, if uneven, improvement in economic conditions and, partly in consequence, an approaching end of the demographic transition. That demographic outcome, indeed, is the future built into the medium-variant population projections of the United Nations, which (in the 2000 revision) portray the world's fertility dropping from 2.8 children per woman in the 1990s to 2.1 ("replacement level") by around 2050, and life expectancy increasing in the same period from 65 years to 74 years. The world population, under this scenario, would rise from 6 billion in 2000 to 9 billion in 2050, but by then the annual increment would have dropped from 80 million people to around 40 million — and zero (and perhaps negative) population growth would be in sight. Closely tied to these trends would be a substantial aging of population, continued rapid urbanization in the less developed regions, and continuation of the major shift in the balance of world population toward the South.

Both in evaluating this scenario and in probing its ingredients, consensus quickly wanes. The range of interpretations of the past experience are magnified in looking ahead. The most sanguine outlook is sketched by Richard A. Easterlin (1996), for whom the population explosion is a passing phenomenon, ushering in a future of sustained economic growth led by ever-higher material aspirations. Erstwhile poor countries successively build the complex economies and settlement densities already found in the rich countries. The process of economic globalization that is underway is frequently depicted as a route to affluence open to all, although bringing with it not just new opportunities but also new systemic fragilities.

More cautious or circumspect assessments of the future extrapolate emerging problems as well as favorable trends. Such problems include: supporting the necessary 
scale of transfer payments to the aged as their numbers multiply; avoiding fertility collapse to levels far below replacement, with its eventual implication of radical population decline; maintaining the quality of socialization and education of children in the face of crumbling families and local communities; lessening the ecological damage associated with rising average consumption levels; and coping not only with the large remaining public health agenda in poor regions but also with new or reemerging infectious disease threats. The future food situation, though in the aggregate far from dire by many informed accounts, is increasingly technology-dependent and regionally disparate. The greenhouse effect, the atmospheric warming caused by increased amounts of carbon dioxide and other gases, has the potential to create ramifying changes in the environment, affecting crop production (perhaps positively), disease vectors, natural ecosystems, sea levels, and weather patterns. Greenhouse gas emissions are linked to population growth as well as to industrialization.

Population change can have political consequences; and political developments, in turn, clearly have the capacity to modify future economic and demographic trends. "Failed states," according to Robert D. Kaplan (1996), owe their ungovernability partly to population growth and the resource scarcities and urban congestion tied to it. Environmentally related political instability, some have argued, will become common in many regions. But while examples of economic retrogression and associated political turbulence will surely continue to be found in the future, so too will cases of recovery and eventual return to paths of stable positive growth.

At the international level, the drastic changes in population-size relativities among countries that are in train must have major political implications. Combined with persisting economic differences, they create faultlines for international conflict. International migration from poor to prosperous countries is another politically sensitive issue that will not lessen in importance-filling some part of the demographic deficit created by very low fertility, and in doing so forming the increasingly ethnically diverse populations of the Western world. There is scant sign that the subject of population and development will become chiefly of interest to historians. 


\section{BIBLIOGRAPHY}

Barnett, Harold J. and Chandler Morse. 1963. Scarcity and Growth: The Economics of Natural Resource Availability. Baltimore: Johns Hopkins Press.

Becker, Gary S. 1990. A Treatise on the Family. Enlarged edition. Cambridge, MA: Harvard University Press.

Birdsall, Nancy, Allen C. Kelley, and Steven W. Sinding, eds. 2001. Population Matters: Demographic Change, Economic Growth, and Poverty in the Developing World. Oxford: Oxford University Press.

Bongaarts, John and Susan Cotts Watkins. 1996. "Social interactions and contemporary fertility transitions," Population and Development Review 22: 639-682.

Boserup, Ester. 1981. Population and Technological Change: A Study of Long-Term Trends. Chicago: University of Chicago Press.

Caldwell, John C. 1982. Theory of Fertility Decline. New York: Academic Press.

Caldwell. John C. 1986. "Routes to low mortality in poor countries," Population and Development Review 12: 171-220.

Chesnais, Jean-Claude. 1986. La transition démographique: etapes, formes, implications économiques. Paris: Presses universitaires de France.

Cleland, John and Chris Wilson. 1987. "Demand theories of the fertility decline: An iconoclastic view," Population Studies 41: 5-30.

Coale, Ansley J. and Edgar M. Hoover. 1958. Population Growth and Economic Development in Low-Income Countries. Princeton: Princeton University Press.

Coale, Ansley J. and Susan Cotts Watkins, eds. 1986. The Decline of Fertility in Europe. Princeton: Princeton University Press.

Easterlin, Richard A. 1996. Growth Triumphant: The Twenty-first Century in Historical Perspective. Ann Arbor: University of Michigan Press.

Hardin, Garrett. 1968. "The tragedy of the commons," Science 162: 1243-1248.

Hirsch, Fred. 1976. Social Limits to Growth. Cambridge, MA: Harvard University Press. 
Kaplan, Robert D. 1996. The Ends of the Earth: A Journey at the Dawn of the Twentyfirst Century. New York: Random House.

Maddison, Angus. 1995. Monitoring the World Economy 1820-1992. Paris: Organisation for Economic Co-operation and Development.

Maddison, Angus. 2001. The World Economy: A Millennial Perspective. Paris: Organisation for Economic Co-operation and Development.

Montgomery, Mark R. and Barney Cohen, eds. 1998. From Death to Birth: Mortality Decline and Reproductive Change. Washington, DC: National Academy Press.

Ohbuchi, Hiroshi. 1976. "Demographic transition in the process of Japanese industrialization," in Hugh Patrick (ed.), Japanese Industrialization and Its Social Consequences. Berkeley: University of California Press.

Preston, Samuel H. 1975. "The changing relation between mortality and level of economic development," Population Studies 29: 231-248.

Pritchett, Lant H. 1994. "Desired fertility and the impact of population policies," Рориlation and Development Review 20: 1-55.

Taussig, Frank W. 1911. Principles of Economics. New York: Macmillan.

United Nations, Population Division. 2001. World Population Prospects: The 2000 Revision. New York.

US National Academy of Sciences. 1971. Rapid Population Growth: Consequences and Policy Implications. Washington, DC: Baltimore: National Academy Press.

US National Academy of Sciences. 1986. Population Growth and Economic Development: Policy Questions. Washington, DC: National Academy Press.

World Bank. 1993. World Development Report 1993. New York: Oxford University Press.

World Bank. 2002. World Development Indicators, 2002. Washington, DC.

Wrigley, E.A. and R.S. Schofield. 1981. The Population History of England 1541-1871: A Reconstruction. Cambridge, MA: Harvard University Press. 


\title{
POLICY RESEARCH DIVISION WORKING PAPERS
}

\author{
Recent Back Issues
}

144 John Bongaarts, "Household size and composition in the developing world."

145 John B. Casterline, Zeba A. Sathar, and Minhaj ul Haque, "Obstacles to contraceptive use in Pakistan: A study in Punjab."

146 Zachary Zimmer, Albert I. Hermalin, and Hui-Sheng Lin, "Whose education counts? The impact of grown children's education on the physical functioning of their parents in Taiwan."

147 Philomena Nyarko, Brian Pence, and Cornelius Debpuur, "Immunization status and child survival in rural Ghana."

*148 John Bongaarts and Zachary Zimmer, "Living arrangements of older adults in the developing world: An analysis of DHS household surveys."

149 Markos Ezra, "Ecological degradation, rural poverty, and migration in Ethiopia: A contextual analysis."
150 Cynthia B. Lloyd, Sahar El Tawila, Wesley H. Clark, and Barbara S. Mensch, "Determinants of educational attainment among adolescents in Egypt: Does school quality make a difference?"

151 Barbara S. Mensch, Paul C. Hewett, and Annabel Erulkar, "The reporting of sensitive behavior among adolescents: A methodological experiment in Kenya."

152 John Bongaarts, "The end of the fertility transition in the developed world."

153 Mark R. Montgomery, GebreEgziabher Kiros, Dominic Agyeman, John B. Casterline, Peter Aglobitse, and Paul Hewett, "Social networks and contraceptive dynamics in southern Ghana."

*154 Paul C. Hewett and Mark R. Montgomery, "Poverty and public services in developing-country cities."

* No longer available 
155 Zachary Zimmer, Linda G. Martin, and Ming-Cheng Chang, "Changes in functional limitations and survival among the elderly in Taiwan: 1993, 1996, and 1999."

156 John Bongaarts and Griffith Feeney, "How long do we live?"

157 Zachary Zimmer and Sovan Kiry Kim, "Living arrangements and socio-demographic conditions of older adults in Cambodia."

158 Geoffrey McNicoll, "Demographic factors in East Asian regional integration."

159 Carol E. Kaufman, Shelley Clark, Ntsiki Manzini, and Julian May, "How community structures of time and opportunity shape adolescent sexual behavior in South Africa."

*160 Julia Dayton and Martha Ainsworth, "The elderly and AIDS: Coping strategies and health consequences in rural Tanzania."

161 John Bongaarts, "The end of the fertility transition in the developing world."
162 Naomi Rutenberg, Carol E. Kaufman, Kate Macintyre, Lisanne Brown, and Ali Karim, "Pregnant or positive: Adolescent childbearing and HIV risk in South Africa."

163 Barbara S. Mensch, Wesley H. Clark, and Dang Nguyen Anh, "Premarital sex in Vietnam: Is the current concern with adolescent reproductive health warranted?"

164 Cynthia B. Lloyd, Cem Mete, and Zeba A. Sathar, "The effect of gender differences in primary school access, type, and quality on the decision to enroll in rural Pakistan."

165 Kelly Hallman, Agnes R. Quisumbing, Marie Ruel, and Bénédicte de la Brière, "Childcare, mothers' work, and earnings: Findings from the urban slums of Guatemala City."

*166 Carol E. Kaufman and Stavros E. Stavrou, "Bus fare, please': The economics of sex and gifts among adolescents in urban South Africa."

*167 Dominic K. Agyeman and John B. Casterline, "Social organization and reproductive behavior in southern Ghana."

* No longer available 
168 Paul C. Hewett, Annabel S. Erulkar, and Barbara S. Mensch, "The feasibility of computer-assisted survey interviewing in Africa: Experience from two rural districts in Kenya."

169 Zachary Zimmer and Julia Dayton, "The living arrangements of older adults in sub-Saharan Africa in a time of HIV/AIDS."

170 Ravai Marindo, Steve Pearson, and John B. Casterline, "Condom use and abstinence among unmarried young people in Zimbabwe: Which strategy, whose agenda?"

171 Sajeda Amin and Nagah H. AlBassusi, "Wage work and marriage: Perspectives of Egyptian working women."
172 Zachary Zimmer, Napaporn Chayovan, Hui-Sheng Lin, and Josefina Natividad, "How indicators of socioeconomic status relate to physical functioning of older adults in three Asian societies."

173 Paul Demeny, "Population policy: A concise summary."

174 Geoffrey McNicoll, "Population and development: An introductory view." 


\title{
Population and Development: An Introductory View
}

\author{
Geoffrey McNicoll
}

2003 No. 174 